\title{
Combined Pig Slurry and Mineral Fertilization for Corn Cultivation
}

\author{
Maritane Prior ${ }^{1 *}$, Silvio César Sampaio ${ }^{2}$, Lúcia Helena Pereira Nóbrega ${ }^{2}$, Miguel Angel \\ Uribe Opazo $^{2}$, Jonhatan Dieter ${ }^{2,3}$ and Thaisa Pegoraro ${ }^{2}$ \\ ${ }^{1}$ Universidade Estadual do Oeste do Paraná; Campus Marechal Cândido Rondon, 1777; 85960-000; Marechal \\ Cândido Rondon - PR - Brasil. ${ }^{2}$ Unversidade Estadual do Oeste do Paraná, Campus Cascavel, 2069; 85819-020; \\ Cascavel - PR - Brasil. ${ }^{3}$ Universidade Federal do Paraná; Setor Palotina - Rua Pioneira, 2153; 85950-00; \\ Palotina - PR - Brasil
}

\begin{abstract}
The objective of this work was to evaluate the environmental effects of the use of pig slurry to irrigate the corn crop grown in a typical Red Distroferric Latosol and in leachate composition. Twenty four lysimeters, filled with soil, in a protected environment, received five doses of pig slurry $\left(0 ; 112.5 ; 225 ; 337.5\right.$ and $450 \mathrm{~m}^{3} \mathrm{ha}^{-1}$ per growing cycle) combined with two mineral fertilization doses (50 and 75\% of the recommended dose - $80 \mathrm{~kg} \mathrm{ha}^{-1}$ of nitrogen). Corn height and yield were evaluated, as well as nutrients in the soil and in leachate. From the results obtained in the first year of experiment, it was concluded that the concentrations of nitrate increased by increase of pig slurry application, and thus, it would be necessary to develop further studies in medium and long term.
\end{abstract}

Key words: nitrate leaching, nutrients cycling, Zea mays L.

\section{INTRODUCTION}

Irrigation with wastewaters has been increasing, mainly due to the decreasing availability of water in some regions, as well as due to the presence of large quantities of nutrients, which may increase the crop yield and improve the physical quality of the soil, thus improving the agricultural frontiers. This practice may be envisaged from two perspectives: the ecological and a socialeconomical. In the first case, the application of these wastewaters to irrigate the crops allows to recover part of the organic matter, while minimizing negative aspects that these residues may cause to water bodies; the second one represents a feasible alternative for both, minerals recycling and mineral fertilization reduction (Gomes et al. 2004; Caovilla et al. 2005; Suszek et al. 2005; Frigo et al. 2006; Anami et al. 2007; Baumgarnter et al. 2007; Sampaio et al. 2007; Anami et al. 2008; Dal Bosco et al. 2008a; Pelissari et al. 2009). Swine wastewater, usually referred to as pig slurry, is one of the most abundant effluents applied on soil, which, however, must be properly managed. Due to the difficulty in finding an adequate application for pig slurry generated in pig farms, many farmers apply it to their soils without a previous evaluation of possible impacts of the application in the long term. This is the typical case of the Paraná state in Brazil, which has about 135,000 properties and a pig herd estimated at 6.07 million of animals. This places Brazil at the fourth place in export of pork in the world ranking (Dal Bosco et al. 2008b). In general, irrigation with pig slurry may promote an improvement of soil structure and other

*Author for correspondence: maritanep@yahoo.com.br 
physical properties, since it adds organic matter contained in the animal manure organic compounds. Soil organic matter decreases soil bulk density, increases porosity of soil and water infiltration, as well as storage and cation exchange capacity. Thus, it reduces the abrupt changes of pH by some buffering effects (Freitas et al. 2004; Anami et al. 2008). However, environmental issues must be studied, as indiscriminate use of the slurry may cause short term ion concentrations in soil, thus generating fertility problems and over concentration in surface and groundwater. Besides the ions, when pig slurry is applied to the soil, nitrogen (Payet et al. 2009; Rotz 2011), phosphorus (Berwanger et al. 2008; Doblinski et al. 2010), exchangeable cations, $\mathrm{K}, \mathrm{Ca}, \mathrm{Mg}, \mathrm{Na}$, $\mathrm{Cu}, \mathrm{Zn}$ and $\mathrm{Mg}$ contents increase (Melo et al. 2006; Berenguer et al. 2008), and salinity and sodicity are closely associated with the practice (Halliwell et al. 2001; Barros et al. 2005; Brito et al. 2007).

In this context, this study aimed at evaluating the effects caused by the pig slurry application associated with mineral fertilization in chemical parameters of a Red Distroferric Latossol and the movement of ions in soil, using drainage lysimeters in corn crop.

\section{MATERIALS AND METHODS}

The experiment was carried out in an experimental field located at $2448^{\prime}$ latitude $\mathrm{S}$ and 53 26' longitude $\mathrm{W}$ and an altitude of $760 \mathrm{~m}$, under protected environment in 24 lysimeters, built according to Aboukhaled, Alfaro and Smith (1986). Spacing between each lysimeter was 0.40 x $0.50 \mathrm{~m}$, a $1.10 \mathrm{~m}$ depth and $1.43 \mathrm{~m}$ diameter each, with $1.0 \mathrm{~m}^{3}$ volume, resulting in a $1.60 \mathrm{~m}^{2}$ area for each one. Water was added to the lysimeters for 45 days to obtain the saturation and accommodation of the soil in order to give a bulk density as close as possible to the conditions at the original sites of the typical Red Distroferric Latosol (EMBRAPA 1999).

A drip tape irrigation system was used to allow a better control of water depths. The drip irrigation emitters were separated by $10 \mathrm{~cm}$, with a flow rate of $1.02 \mathrm{~L} \mathrm{~h}^{-1}$ and a service pressure of $5 \mathrm{mWG}$. This irrigation system was used to simulate the average water regime of the region $(75 \%$ of probability) (Longo et al. 2006).
Hybrid corn (Zea mays L.) CD 705, recommended for the region, was sown with a density corresponding to 45,000 plants $\mathrm{ha}^{-1}$. Seeding was carried out manually, with two seeds per pit. There were eleven pits per lysimeter and thinning was carried out five days after the seeding (DAS). After the thinning, eleven plants were left in each lysimeter. Liming requirement was supplied according to Gianello et al. (1995). Considering nitrogen $(\mathrm{N})$ as a key element, treatments were determined by crop $\mathrm{N}$ requirements $\left(80 \mathrm{~kg} \mathrm{ha}^{-1}\right)$ (Fancelli and Dourado Neto 2000), according to the chemical composition of mineral fertilizer $(\mathrm{N}-$ $5 \%$; P-20\%; K-20\%) and physico-chemical characteristics of pig slurry (Table 1).

A trifactorial split-plot block experimental design was used (B1, B2, B3), with three replicates. Due to previous use of the experimental field, a longitudinal heterogeneity was observed in soil parameters, which led to the use of a randomized block design. The treatments used were (Table 3): five doses of pig slurry corresponding to $0,112.5$, $225,337.5$ and $450 \mathrm{~m}^{3} \mathrm{ha}^{-1}$ during corn cycle, combined with two levels of fertilization (50 and $75 \%$ of recommended nitrogen fertilization). Pig slurry doses were split in six pig applications, from the vegetative cycle to the reproductive cycle of the crop. Controls consisted of crop growth with the two doses of traditional mineral fertilization only $(50$ or $75 \%)$ and $0 \mathrm{~m}^{3} \mathrm{ha}^{-1}$ pig slurry. During the experiment, five samplings of soil were performed (0, 40, 70, 95 and 200 DAS).

Lysimeters leachate was collected seven times (60, $75,90,105,120,135$ and 150 DAS) and plant height $(\mathrm{PH})$ was measured five times $(10,40,70$, 100 and 130 DAS). Productivity in each plot was determined at the end of the crop cycle. Considering that $\mathrm{NO}_{3}$ (Table 1) is the assimilable form of $\mathrm{N}$ by the crop, the doses 112.5 and $225 \mathrm{~m}^{3}$ $\mathrm{ha}^{-1}$ were below the ideal rate, while the doses 337.5 and $450 \mathrm{~m}^{3} \mathrm{ha}^{-1}$ surpassed the recommendation for the crop. The normality analyses of data and the respective transformations, when necessary, followed Gomes (1987) recommendation. After the test of normality, the analyses of variance were carried out to check the significance of factors under the study. When there were significant interactions among the means, they were compared by Tukey test at $5 \%$ significance. 
Table 1 - Chemical characteristics of pig slurry.

\begin{tabular}{|c|c|}
\hline Parameters & Results \\
\hline $\mathrm{pH}$ & 7.70 \\
\hline $\mathrm{EC}\left(\mathrm{mS} \mathrm{cm}^{-1}\right)$ & 6.77 \\
\hline $\mathrm{BOD}\left(\mathrm{mg} \mathrm{L}^{-1}\right)$ & 2406 \\
\hline $\mathrm{COD}\left(\mathrm{mg} \mathrm{L}^{-1}\right)$ & 3048 \\
\hline $\mathrm{NO}_{3}\left(\mathrm{mg} \mathrm{L}^{-1}\right)$ & 35 \\
\hline $\mathrm{TKN}\left(\mathrm{g} \mathrm{L}^{-1}\right)$ & 1.75 \\
\hline $\mathrm{P}\left(\mathrm{mg} \mathrm{L}^{-1}\right)$ & 171 \\
\hline $\mathrm{K}\left(\mathrm{mg} \mathrm{L}^{-1}\right)$ & 150 \\
\hline $\operatorname{Mg}\left(\mathrm{mg} \mathrm{L}^{-1}\right)$ & 7.50 \\
\hline $\mathrm{Ca}\left(\mathrm{mg} \mathrm{L}^{-1}\right)$ & 34.50 \\
\hline $\mathrm{Na}\left(\mathrm{mg} \mathrm{L}^{-1}\right)$ & 93.0 \\
\hline $\mathrm{Cu}\left(\mathrm{mg} \mathrm{L}^{-1}\right)$ & 0.06 \\
\hline $\mathrm{Zn}\left(\mathrm{mg} \mathrm{L}^{-1}\right)$ & 0.38 \\
\hline Total solids $\left(\mathrm{mg} \mathrm{L}^{-1}\right)$ & 5.95 \\
\hline Fixed total solids $\left(\mathrm{mg} \mathrm{L}^{-1}\right)$ & 3.10 \\
\hline Fixed dissolved solids $\left(\mathrm{mg} \mathrm{L}^{-1}\right)$ & 1.78 \\
\hline Volatile dissolved solids $\left(\mathrm{mg} \mathrm{L}^{-1}\right)$ & 2.34 \\
\hline Turbidity (UT) & 940 \\
\hline
\end{tabular}

Table 2 - Physico-chemical characteristics of the lysimeters soil prior to the treatments.

\begin{tabular}{|c|c|c|c|c|c|c|c|c|c|c|}
\hline \multirow{2}{*}{ Blocks } & pH & $\mathbf{O M}$ & $\mathbf{P}$ & $\mathbf{H}+\mathbf{A l}$ & $\mathbf{K}$ & $\mathbf{C a}$ & Mg & SB & CEC & $\mathbf{V}$ \\
\hline & $\mathrm{CaCl}_{2}$ & \multicolumn{2}{|c|}{-.-- $\mathrm{mg} \mathrm{dm}^{-3}$-..- } & \multicolumn{6}{|c|}{ - - - } & $\%$ \\
\hline B1 & 6.40 & 16.0 & 4.0 & 0.20 & 5.06 & 3.56 & 8.82 & 11.56 & 76.30 & 8.82 \\
\hline B2 & 5.10 & 15.0 & 4.0 & 0.18 & 3.0 & 1.59 & 4.77 & 9.38 & 50.85 & 4.77 \\
\hline B3 & 4.90 & 11.0 & 1.0 & 0.06 & 2.16 & 1.27 & 3.49 & 7.77 & 44.92 & 3.49 \\
\hline Means & 5.47 & 14.00 & 3.00 & 3.88 & 0.15 & 3.41 & 2.14 & 5.69 & 9.57 & 57.36 \\
\hline \multirow{2}{*}{ Blocks } & \multicolumn{2}{|c|}{$\mathrm{Mn}$} & $S$ & \multicolumn{2}{|c|}{ B } & \multicolumn{2}{|c|}{$\mathrm{Fe}$} & $\mathrm{Cu}$ & \multicolumn{2}{|c|}{$\mathrm{Zn}$} \\
\hline & \multicolumn{10}{|c|}{ 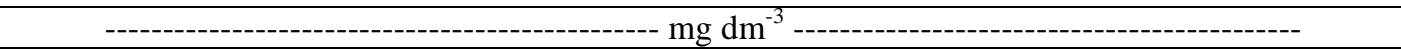 } \\
\hline B1 & \multicolumn{2}{|c|}{56.67} & 2.74 & \multicolumn{2}{|c|}{0.17} & \multicolumn{2}{|c|}{66.24} & 9.23 & \multicolumn{2}{|c|}{1.18} \\
\hline B2 & \multicolumn{2}{|c|}{35.80} & 4.61 & \multicolumn{2}{|c|}{0.07} & \multicolumn{2}{|c|}{64.43} & 8.76 & \multicolumn{2}{|c|}{0.85} \\
\hline B3 & \multicolumn{2}{|c|}{25.30} & 4.28 & \multicolumn{2}{|c|}{0.09} & \multicolumn{2}{|c|}{76.93} & 7.86 & \multicolumn{2}{|c|}{0.43} \\
\hline Means & \multicolumn{2}{|c|}{39.26} & 5.69 & \multicolumn{2}{|c|}{0.11} & \multicolumn{2}{|c|}{69.20} & 8.62 & \multicolumn{2}{|c|}{0.82} \\
\hline
\end{tabular}

Analyses were carried out following Raij et al. (2001) and Tedesco et al. (1999) methodology. OM: organic matter; SB: sum of bases; CEC: cation exchange capacity; V\%: base saturation.

Table 3 - Treatments and corresponding application doses of nutrients.

\begin{tabular}{|c|c|c|c|c|c|c|c|c|c|c|c|c|}
\hline \multirow{2}{*}{$\begin{array}{c}\text { PS } \\
\text { rate }\end{array}$} & \multirow{2}{*}{$\begin{array}{l}\text { LF } \\
(\%)\end{array}$} & \multicolumn{3}{|c|}{$\begin{array}{l}\text { Nutrients dose } \\
(\mathrm{CF}) \mathrm{kg} \mathrm{ha}^{-1}\end{array}$} & \multicolumn{8}{|c|}{ Nutrients dose (PS) } \\
\hline & & $\mathbf{N}$ & $\mathbf{P}$ & $\mathbf{K}$ & $\mathbf{N}$ & $\mathbf{P}$ & $\mathbf{K}$ & $\mathbf{C a}$ & Mg & $\mathbf{N a}$ & $\mathbf{C u}$ & Zn \\
\hline 112.5 & 50 & 15 & 60 & 90 & 85 & 19.23 & 16.87 & 3.88 & 0.84 & 10.46 & 0.007 & 0.042 \\
\hline 112.5 & 75 & 22.5 & 30 & 45 & 77.5 & 19.23 & 16.87 & 3.88 & 0.84 & 10.46 & 0.007 & 0.042 \\
\hline 225 & 50 & 15 & 60 & 90 & 185 & 38.47 & 33.75 & 7.76 & 1.68 & 20.92 & 0.013 & 0.085 \\
\hline 225 & 75 & 22.5 & 30 & 45 & 177.5 & 38.47 & 33.75 & 7.76 & 1.68 & 20.92 & 0.013 & 0.085 \\
\hline 337.5 & 50 & 15 & 60 & 90 & 285 & 57.71 & 50.62 & 11.64 & 2.53 & 31.38 & 0.020 & 0.13 \\
\hline 337.5 & 75 & 22.5 & 30 & 45 & 277.5 & 57.71 & 50.62 & 11.64 & 2.53 & 31.38 & 0.020 & 0.13 \\
\hline 450 & 50 & 15 & 60 & 90 & 385 & 76.95 & 67.50 & 15.52 & 3.37 & 41.85 & 0.027 & 0.17 \\
\hline 450 & 75 & 22.5 & 30 & 45 & 377.5 & 76.95 & 67.50 & 15.52 & 3.37 & 41.85 & 0.027 & 0.17 \\
\hline 0 & 50 & 15 & 60 & 90 & 0 & 0 & 0 & 0 & 0 & 0 & 0 & 0 \\
\hline 0 & 75 & 22.5 & 30 & 45 & 0 & 0 & 0 & 0 & 0 & 0 & 0 & 0 \\
\hline
\end{tabular}

PS: pig slurry; LF: level of fertilization; CF: chemical fertilization. 


\section{RESULTS AND DISCUSSION}

Table 4 shows a summary of the analysis of variance (ANOVA) results for the soil parameters and each treatment. In general, DAS and application of pig slurry, both alone and together, had the most significant effects, since pig slurry application supplied additional nutrients to the crop. This observation indicated the importance of evaluating these effects as a function of pig slurry application time and dose (Hountin et al. 2000). Another important observation was that the parameters associated with total Kjeldahl nitrogen (TKN) and $\mathrm{N}$ organic (Norg) did not show any significant effects, which might have been due to the ability of the crop to adequately extract this element (Singh and Kanwar 1995; Freitas et al. 2004).

Table 4 - Summary of the analyses of variance for all the soil parameters studied, according to all the treatment factors.

\begin{tabular}{|c|c|c|c|c|c|c|c|c|c|c|}
\hline \multirow{2}{*}{$\begin{array}{l}\text { Causes of } \\
\text { Variation }\end{array}$} & \multirow{2}{*}{ DF } & \multicolumn{9}{|c|}{ Parameters } \\
\hline & & TKN & $\mathrm{NO}_{2}$ & $\mathbf{N H}_{4}$ & $N_{\text {org }}$ & $\mathbf{N}_{\text {inorg }}$ & $\mathbf{P}$ & $\mathbf{K}$ & $\mathbf{C a}$ & Mg \\
\hline Block & 2 & $0.12^{\text {ns }}$ & $11.37 *$ & $0.68^{\mathrm{ns}}$ & $0.88^{\text {ns }}$ & $0.01^{\mathrm{ns}}$ & $3.91^{\mathrm{ns}}$ & $5.67^{\mathrm{ns}}$ & $0.19^{\mathrm{ns}}$ & $1.32^{\mathrm{ns}}$ \\
\hline PS & 4 & $0.35^{\mathrm{ns}}$ & $2.80^{\mathrm{ns}}$ & $1.8^{\mathrm{ns}}$ & $1.41^{\mathrm{ns}}$ & $0.7^{\mathrm{ns}}$ & $1.91^{\mathrm{ns}}$ & $32.77^{\mathrm{ns}}$ & $0.86^{\mathrm{ns}}$ & $0.34^{\mathrm{ns}}$ \\
\hline Error I & 8 & & & & & & & & & \\
\hline $\mathrm{CF}$ & 1 & $3.17^{\text {ns }}$ & $0.09^{\mathrm{ns}}$ & $0.49^{\mathrm{ns}}$ & $2.89^{\text {ns }}$ & $0.14^{\mathrm{ns}}$ & $3.04^{\mathrm{ns}}$ & $1.23^{\mathrm{ns}}$ & $1.71^{\mathrm{ns}}$ & $2.14^{\mathrm{ns}}$ \\
\hline $\mathrm{PS} * \mathrm{CF}$ & 4 & $0.48^{\mathrm{ns}}$ & $3.26^{\mathrm{ns}}$ & $0.35^{\mathrm{ns}}$ & $0.49^{\mathrm{ns}}$ & $1.21^{\mathrm{ns}}$ & $1.75^{\mathrm{ns}}$ & $0.16^{\mathrm{ns}}$ & $2.33^{\text {ns }}$ & $0.09^{\text {ns }}$ \\
\hline Error II & 10 & & & & & & & & & \\
\hline DAS & 4 & $0.84^{\mathrm{ns}}$ & $7.85^{*}$ & $19.22^{*}$ & $1.04^{\mathrm{ns}}$ & $2.98^{*}$ & $16.02 *$ & $44.56^{*}$ & $14.11^{*}$ & $10.21 *$ \\
\hline $\mathrm{PS} * \mathrm{DAS}$ & 16 & $0.21^{\mathrm{ns}}$ & $1.94 *$ & $2.14 *$ & $0.27^{\mathrm{ns}}$ & $1.41^{\mathrm{ns}}$ & $2.68 *$ & $3.72 *$ & $2.94 *$ & $0.58^{\mathrm{ns}}$ \\
\hline $\mathrm{CF}^{*} \mathrm{DAS}$ & 4 & $0.95^{\mathrm{ns}}$ & $0.14^{\mathrm{ns}}$ & $0.7^{\mathrm{ns}}$ & $1.53^{\mathrm{ns}}$ & $0.26^{\mathrm{ns}}$ & $3.68 *$ & $2.31^{\mathrm{ns}}$ & $0.40^{\mathrm{ns}}$ & $0.08^{\mathrm{ns}}$ \\
\hline $\mathrm{PS} * \mathrm{CF} * \mathrm{DAS}$ & 16 & $0.56^{\mathrm{ns}}$ & $2.10^{\mathrm{ns}}$ & $0.7^{\mathrm{ns}}$ & $0.36^{\mathrm{ns}}$ & $1.01^{\mathrm{ns}}$ & $1.54^{\mathrm{ns}}$ & $1.47^{\mathrm{ns}}$ & $1.21^{\mathrm{ns}}$ & $0.58^{\mathrm{ns}}$ \\
\hline Block*DAS & 8 & $0.24^{\mathrm{ns}}$ & $2.84 *$ & $2.53 *$ & $0.17^{\mathrm{ns}}$ & $1.47^{\mathrm{ns}}$ & $1.66^{\mathrm{ns}}$ & $1.58^{\mathrm{ns}}$ & $0.46^{\mathrm{ns}}$ & $0.43^{\mathrm{ns}}$ \\
\hline Error III & 72 & & & & & & & & & \\
\hline Total & 149 & & & & & & & & & \\
\hline CV I (\%) & & 11.69 & 12.84 & 9.09 & 10.46 & 16.32 & 47.92 & 12.46 & 20.15 & 27.95 \\
\hline CV II (\%) & & 11.85 & 22.99 & 6.61 & 9.69 & 18.03 & 36.97 & 17.41 & 18.20 & 24.58 \\
\hline CV III (\%) & & 16.65 & 20.23 & 9.12 & 18.21 & 17.85 & 27.07 & 16.20 & 15.20 & 13.77 \\
\hline \multirow{2}{*}{$\begin{array}{l}\text { Causes of } \\
\text { Variation }\end{array}$} & \multirow{2}{*}{$\mathrm{DF}$} & \multicolumn{9}{|c|}{ Parameters } \\
\hline & & $\mathrm{Cu}$ & $\mathrm{Zn}$ & $\mathrm{Fe}$ & $\mathrm{Mn}$ & $\mathrm{pH}$ & $\mathrm{OM}$ & $\mathrm{EC}$ & SAR & PST \\
\hline Block & 2 & $1.72^{\mathrm{ns}}$ & $4.74^{\mathrm{ns}}$ & $0.29^{\mathrm{ns}}$ & $3.06^{\mathrm{ns}}$ & $9.29 *$ & $1.32^{\mathrm{ns}}$ & $0.57^{\mathrm{ns}}$ & $0.77^{\mathrm{ns}}$ & $0.03^{\mathrm{ns}}$ \\
\hline PS & 4 & $0.049^{\mathrm{ns}}$ & $2.27^{\mathrm{ns}}$ & $1.94^{\mathrm{ns}}$ & $1.68^{\mathrm{ns}}$ & $8.32 *$ & $0.34^{\mathrm{ns}}$ & $2.52^{\mathrm{ns}}$ & $2.79^{\mathrm{ns}}$ & $0.47^{\mathrm{ns}}$ \\
\hline Error I & 8 & & & & & & & & & \\
\hline $\mathrm{CF}$ & 1 & $1.93^{\mathrm{ns}}$ & $8.42 *$ & $0.86^{\mathrm{ns}}$ & $3.87^{\mathrm{ns}}$ & $0.32^{\mathrm{ns}}$ & $2.14^{\mathrm{ns}}$ & $0.58^{\mathrm{ns}}$ & $0.46^{\mathrm{ns}}$ & $0.16^{\mathrm{ns}}$ \\
\hline $\mathrm{PS} * \mathrm{CF}$ & 4 & $0.37^{\mathrm{ns}}$ & $0.85^{\mathrm{ns}}$ & $0.58^{\mathrm{ns}}$ & $0.06^{\mathrm{ns}}$ & $1.22^{\mathrm{ns}}$ & $0.09^{\mathrm{ns}}$ & $5.59 *$ & $2.18^{\mathrm{ns}}$ & $0.77^{\mathrm{ns}}$ \\
\hline Error II & 10 & & & & & & & & & \\
\hline DAS & 4 & $31.9 *$ & $40.9^{*}$ & $50.5^{*}$ & $0.09^{\text {ns }}$ & $11.8^{*}$ & $10.2 *$ & $8.67 *$ & $13.24 *$ & $10.39 *$ \\
\hline PS*DAS & 16 & $2.79 *$ & $4.07 *$ & $5.31 *$ & $1.58^{\mathrm{ns}}$ & $0.94^{\mathrm{ns}}$ & $0.58^{\mathrm{ns}}$ & $1.96^{\mathrm{ns}}$ & $2.85^{*}$ & $2.55^{*}$ \\
\hline $\mathrm{CF}^{*} \mathrm{DAS}$ & 4 & $0.14^{\mathrm{ns}}$ & $0.75^{\mathrm{ns}}$ & $0.45^{\mathrm{ns}}$ & $0.1^{\mathrm{ns}}$ & $0.56^{\mathrm{ns}}$ & $0.08^{\mathrm{ns}}$ & $0.58^{\mathrm{ns}}$ & $0.85^{\mathrm{ns}}$ & $1.59^{\mathrm{ns}}$ \\
\hline PS*CF*DAS & 16 & $0.66^{\mathrm{ns}}$ & $0.58^{\mathrm{ns}}$ & $2.02^{\mathrm{ns}}$ & $0.42^{\mathrm{ns}}$ & $0.40^{\mathrm{ns}}$ & $0.58^{\mathrm{ns}}$ & $0.84^{\mathrm{ns}}$ & $1.059^{\mathrm{ns}}$ & $1.38^{\mathrm{ns}}$ \\
\hline Block*DAS & 8 & $3.65^{*}$ & $9.01 *$ & $2.08^{\mathrm{ns}}$ & $0.96^{\mathrm{ns}}$ & $1.60^{\mathrm{ns}}$ & $0.43^{\mathrm{ns}}$ & $1.01^{\mathrm{ns}}$ & $2.81 *$ & $1.94^{\mathrm{ns}}$ \\
\hline Error III & 72 & & & & & & & & & \\
\hline Total & 149 & & & & & & & & & \\
\hline CV I (\%) & & 37.15 & 36.34 & 11.13 & 21.83 & 7.16 & 27.95 & 45.18 & 3.58 & 24.75 \\
\hline CV II (\%) & & 38.66 & 28.13 & 10.33 & 19.84 & 13.67 & 24.58 & 21.36 & 2.78 & 40.63 \\
\hline CV III (\%) & & 18.47 & 27.27 & 10.90 & 14.50 & 5.70 & 13.77 & 45.32 & 3.16 & 19.95 \\
\hline
\end{tabular}

CF: fertilization, PG: pig slurry; DF: Degrees of freedom; DAS: days after seeding; CV: coefficient of variation; TKN: total Kjeldahl nitrogen; OM: organic matter; EC: electrical conductivity; SAR: sodium adsorption ratio; ESP: exchangeable sodium percentage. ${ }^{\text {ns. }}$ : not significant at $5 \%$ of probability; *:significant at $5 \%$ of probability.

Tables 5,6 and 7 show the results for the means comparison tests for identifying the significant effects of the interactions or isolated factors in
Table 4. Similar to soil parameters, the factors which had the most significant effects on the leachate were DAS and pig slurry, both 
individually and together (Table 8). This showed the importance of evaluating these effects as a function of slurry application time and dose (Hountin et al. 2000).

It is important to note that the Chemical Factor (CF) factor mainly influenced the electrical conductivity (EC) when combined with DAS. Tables 9 and 10 show the means comparison tests for identifying the significant effects of the interactions or isolated factors in Table 8.

\section{Nitrogen}

Initial soil inorganic N concentration of $65.59 \mathrm{mg}$ $\mathrm{L}^{-1}$ increased after the application of pig slurry (Table 5). At the end of the growing cycle at 200
DAS, inorganic $\mathrm{N}$ levels decreased, which could be related to the following two factors: either the plants absorbed $\mathrm{N}$ or $\mathrm{N}$ was leached into deeper soil layers because pig slurry was not applied during the reproductive period (Alfaia 2006). In the leachates, $\mathrm{NO}_{3}$ concentration increased proportionally according to the treatments (Table 9). Despite this increase, all of the measured amounts were below the recommended environmental limits in Brazil $\left(10 \mathrm{mg} \mathrm{L}^{-1}\right)$ (CONAMA 2008). TKN was undetectable in the leachate at the beginning of crop growth, but this changed with continued application of pig slurry, thus revealing leaching of this nutrient (Table 10).

Table 5 - Tukey test for significant parameters of soil in the interaction $\mathrm{CF}^{*} \mathrm{DAS}(\mathrm{P})$, between the levels of pig slurry (pH and EC) and between levels of DAS (TKN, Norg, Ninorg, Mg, OM).

\begin{tabular}{|c|c|c|c|c|c|}
\hline \multirow[b]{2}{*}{ CF $(\%)$} & \multicolumn{4}{|c|}{ DAS } & \multirow[b]{2}{*}{125} \\
\hline & $\mathbf{0}$ & 40 & 70 & 90 & \\
\hline \multicolumn{6}{|c|}{$\mathrm{P}\left(\mathrm{mg} \mathrm{L}^{-1}\right)$} \\
\hline 50 & $11.39 \mathrm{bB}$ & $14.93 \mathrm{abA}$ & $17.50 \mathrm{abA}$ & $22.17 \mathrm{aA}$ & $15.46 \mathrm{abA}$ \\
\hline 75 & $13.87 \mathrm{bA}$ & $14.93 \mathrm{bA}$ & $15.46 \mathrm{bA}$ & $24.47 \mathrm{aA}$ & $18.57 \mathrm{bA}$ \\
\hline \multicolumn{6}{|c|}{ Pig Slurry $\left(\mathrm{m}^{3} \mathrm{ha}^{-1}\right)$} \\
\hline Parameter & $\mathbf{0}$ & 112.5 & 225 & 337.5 & 450 \\
\hline $\mathrm{pH}$ & $5.96 \mathrm{~b}$ & $6.30 \mathrm{ab}$ & $6.29 \mathrm{ab}$ & $6.30 \mathrm{ab}$ & $6.42 \mathrm{a}$ \\
\hline $\mathrm{EC}$ & $0.09 \mathrm{~b}$ & $0.10 \mathrm{~b}$ & $0.11 \mathrm{ab}$ & $0.10 \mathrm{ab}$ & $0.14 \mathrm{a}$ \\
\hline \multicolumn{6}{|c|}{ DAS } \\
\hline Parameter & $\mathbf{0}$ & 40 & 70 & 95 & 200 \\
\hline TKN $\left(\mathrm{mg} \mathrm{L}^{-1}\right)$ & $1817.66 \mathrm{a}$ & $1818.93 a$ & $1844.23 \mathrm{a}$ & $1838.06 a$ & $1852.10 \mathrm{a}$ \\
\hline $\operatorname{Norg}\left(\mathrm{mg} \mathrm{L}^{-1}\right)$ & $1773.17 \mathrm{a}$ & $1740.60 \mathrm{a}$ & $1864.36 a$ & $1705.46 a$ & $1797.60 \mathrm{a}$ \\
\hline Ninorg $\left(\mathrm{mg} \mathrm{L}^{-1}\right)$ & $65.59 \mathrm{~b}$ & $73.46 \mathrm{ab}$ & $75.66 \mathrm{a}$ & $73.83 \mathrm{ab}$ & $69.59 b$ \\
\hline $\operatorname{Mg}\left(\mathrm{mg} \mathrm{L}^{-1}\right)$ & $2.65 c$ & $4.00 \mathrm{~b}$ & $4.06 \mathrm{~b}$ & $4.10 \mathrm{~b}$ & $5.31 \mathrm{a}$ \\
\hline $\mathrm{OM}\left(\mathrm{g} \mathrm{dm}^{-3}\right)$ & $20.56 \mathrm{c}$ & $21.90 \mathrm{bc}$ & $24.10 \mathrm{ab}$ & $25.16 \mathrm{a}$ & $23.93 \mathrm{ab}$ \\
\hline
\end{tabular}

Means followed by the same letter in the row and capital letter in the column do not differ among themselves by Tukey test at the level of 5\% significance. DAS: days after seeding; CF: chemical fertilization; EC: electrical conductivity; TKN: total Kjeldahl nitrogen; OM: organic matter.

\section{Phosphorus}

Pig slurry application slightly increased the available phosphorus (P) levels in the soil (Tables 5 and 6) because pig slurry was rich in $\mathrm{P}$ (Table 1), which was not mobile in the soil. Additionally, organic matter helps $\mathrm{P}$ to remain exchangeable (Oliveira and Parizotto 1994; Oliveira et al. 2000).

As shown in Table 5, only the control was significantly different with the largest $\mathrm{P}$ dose at 75\% CF. Despite the differences in the control, soil $\mathrm{P}$ concentrations were low compared to the values found by Stefanutti et al. (1995), who reported concentrations greater than $24 \mathrm{mg} \mathrm{L}^{-1}$ leading to soil contamination problems. At 90 DAS, soil P levels were higher than the level determined by Stefanutti et al. (1995). However, the levels began to decrease at 200 DAS when pig slurry was no longer applied. The amount of $\mathrm{P}$ leaching in the soil profile after slurry application was small, with the highest concentration at the end of the analyzed time period (Table 10).

Lowest concentrations of $\mathrm{P}$ are generally due to adsorption to soil particles, plant absorption and/or precipitation (Ceretta et al. 2005).

Eghball et al. (1997) applied $60 \mathrm{~kg} \mathrm{ha}^{-1}$ of $\mathrm{P}$ in layers and found that $\mathrm{P}$ descended only $4 \mathrm{~cm}$ in three types of soil. Several studies have shown that $\mathrm{P}$ leaches more easily in the soil when $\mathrm{P}$ is in organic form and when fertilizers and organic materials are applied together. $\mathrm{P}$ concentrations in the leachate were always lower than the range $(0.2$ to $0.3 \mathrm{mg} \mathrm{L}^{-1}$ ) reported to be the usual leachate water concentration during plant growth by Basso et al. (2005). 
Even though $\mathrm{P}$ was not found at high concentrations, it should be monitored for potential environmental pollution. The application of high doses of pig slurry in small areas, and practices allowing higher water infiltration rates should be avoided. Agricultural systems, which allow the production and maintenance of large amounts of plant material on the soil surface to decrease surface erosion, should be adopted. In some cases, however, even small losses of $\mathrm{P}$ at relatively low concentrations are considered critical enough to cause water eutrophication (Zaimes and Schultz 2002).

\section{SAR, ESP and related cations}

The application of pig slurry generally resulted in increased calcium $(\mathrm{Ca})$ and potassium $(\mathrm{K})$ soil concentrations during the growing cycle (Table 6).

Table 6 - Tukey test for the significant parameters of soil, in the interaction PS*DAS $\left(\mathrm{NO}_{3}, \mathrm{NH}_{4}, \mathrm{P}, \mathrm{K}, \mathrm{Ca}\right)$.

\begin{tabular}{|c|c|c|c|c|c|}
\hline \multirow[t]{3}{*}{ SW $\left(\mathrm{m}^{3} \mathrm{ha}^{-1}\right)$} & \multicolumn{5}{|c|}{ DAS } \\
\hline & $\mathbf{0}$ & 40 & 70 & 95 & 200 \\
\hline & \multicolumn{5}{|c|}{$\mathrm{NO}_{3}\left(\mathrm{mg} \mathrm{L}^{-1}\right)$} \\
\hline 0 & $41.86 \mathrm{bA}$ & $60.21 \mathrm{aA}$ & $66.40 \mathrm{aA}$ & $47.85 \mathrm{bB}$ & $43.53 \mathrm{bA}$ \\
\hline 112.5 & $38.00 \mathrm{bB}$ & $58.44 \mathrm{aA}$ & $58.08 \mathrm{aA}$ & 49.79abAB & 48.98abA \\
\hline 225 & $51.75 \mathrm{aAB}$ & $53.29 \mathrm{aA}$ & $57.67 \mathrm{aA}$ & $56.87 \mathrm{aAB}$ & $46.82 \mathrm{aA}$ \\
\hline 337.5 & $41.7 \mathrm{bA}$ & $58.62 \mathrm{abA}$ & $63.23 \mathrm{aA}$ & $60.41 \mathrm{aAB}$ & $51.85 \mathrm{bA}$ \\
\hline \multirow[t]{2}{*}{450} & $51.80 \mathrm{abAB}$ & $56.47 \mathrm{abA}$ & $55.36 \mathrm{abA}$ & $67.39 \mathrm{aA}$ & $46.89 \mathrm{bA}$ \\
\hline & \multicolumn{5}{|c|}{$\mathrm{NH}_{4}\left(\mathrm{mg} \mathrm{L}^{-1}\right)$} \\
\hline 0 & $4.21 \mathrm{aA}$ & $4.47 \mathrm{aA}$ & $4.23 \mathrm{aA}$ & $4.58 \mathrm{aA}$ & $4.37 \mathrm{aA}$ \\
\hline 112.5 & $3.96 \mathrm{bA}$ & $4.06 \mathrm{abA}$ & 4.10abcB & $4.63 \mathrm{aA}$ & $4.70 \mathrm{aA}$ \\
\hline 225 & $3.93 \mathrm{cA}$ & 4.37abA & $4.07 \mathrm{abA}$ & $4.62 \mathrm{aA}$ & $4.86 \mathrm{aA}$ \\
\hline 337.5 & $3.82 \mathrm{bA}$ & 4.16abA & $3.94 \mathrm{bA}$ & $4.68 \mathrm{aA}$ & $4.78 \mathrm{aA}$ \\
\hline \multirow[t]{2}{*}{450} & $4.03 \mathrm{bcA}$ & $4.07 \mathrm{bcA}$ & $3.74 \mathrm{cA}$ & $4.61 \mathrm{abA}$ & $4.86 \mathrm{aA}$ \\
\hline & \multicolumn{5}{|c|}{$\mathrm{P}\left(\mathrm{mg} \mathrm{L}^{-1}\right)$} \\
\hline 0 & $14.62 \mathrm{aAB}$ & $14.66 \mathrm{aA}$ & $14.79 \mathrm{aA}$ & $14.06 \mathrm{aC}$ & $14.26 \mathrm{aB}$ \\
\hline 112.5 & $13.40 \mathrm{bB}$ & $13.89 \mathrm{bA}$ & $13.93 \mathrm{bA}$ & $21.98 \mathrm{aB}$ & $14.38 \mathrm{bB}$ \\
\hline 225 & $16.85 \mathrm{bA}$ & $16.27 \mathrm{bA}$ & $17.03 \mathrm{bA}$ & $26.24 \mathrm{aAB}$ & $22.64 \mathrm{aA}$ \\
\hline 337.5 & $11.22 \mathrm{bB}$ & $13.99 \mathrm{bA}$ & $17.43 \mathrm{abA}$ & $24.63 \mathrm{aAB}$ & $17.05 \mathrm{abAB}$ \\
\hline \multirow[t]{2}{*}{450} & $13.57 \mathrm{bAB}$ & $15.83 \mathrm{bA}$ & $19.22 \mathrm{bA}$ & $29.70 \mathrm{aA}$ & $16.73 \mathrm{bAB}$ \\
\hline & \multicolumn{5}{|c|}{$\mathrm{K}\left(\mathrm{mg} \mathrm{L}^{-1}\right)$} \\
\hline 0 & $2.93 \mathrm{aA}$ & $3.85 \mathrm{aA}$ & $4.06 \mathrm{aA}$ & $3.81 \mathrm{aAB}$ & $3.38 \mathrm{aAB}$ \\
\hline 112.5 & $0.99 \mathrm{bB}$ & 1.39abB & $1.96 \mathrm{abB}$ & $2.39 \mathrm{aB}$ & $2.19 \mathrm{aB}$ \\
\hline 225 & $1.22 \mathrm{cB}$ & $2.33 \mathrm{bcB}$ & $2.27 \mathrm{abB}$ & $3.47 \mathrm{aB}$ & $2.42 \mathrm{abAB}$ \\
\hline 337.5 & $0.85 \mathrm{cB}$ & $1.76 \mathrm{bcB}$ & $2.09 \mathrm{bB}$ & $3.97 \mathrm{aAB}$ & $3.68 \mathrm{aA}$ \\
\hline \multirow[t]{2}{*}{450} & $0.74 \mathrm{cB}$ & $1.64 \mathrm{cB}$ & $3.08 \mathrm{aB}$ & $5.06 \mathrm{aA}$ & $3.54 \mathrm{abA}$ \\
\hline & \multicolumn{5}{|c|}{$\mathrm{Ca}\left(\mathrm{mmol}_{\mathrm{c}} \mathrm{dm}^{-3}\right)$} \\
\hline 0 & $49.16 \mathrm{aA}$ & $46.16 \mathrm{aA}$ & $33.00 \mathrm{aB}$ & $33.00 \mathrm{aB}$ & $38.00 \mathrm{aC}$ \\
\hline 112.5 & $52.83 \mathrm{aA}$ & $62.66 \mathrm{aA}$ & $61.16 \mathrm{aA}$ & $62.83 \mathrm{aA}$ & $60.16 \mathrm{aAB}$ \\
\hline 225 & $68.50 \mathrm{aA}$ & $63.00 \mathrm{aA}$ & $66.83 \mathrm{aA}$ & $49.16 \mathrm{aA}$ & $56.66 \mathrm{aBC}$ \\
\hline 337.5 & $51.33 \mathrm{aA}$ & $53.66 \mathrm{~A}$ & $58.83 \mathrm{aA}$ & $66.16 \mathrm{aA}$ & $71.00 \mathrm{aAB}$ \\
\hline 450 & $45.00 \mathrm{bA}$ & $57.66 \mathrm{bA}$ & $68.33 \mathrm{abA}$ & $94.66 \mathrm{aA}$ & $94.66 \mathrm{aA}$ \\
\hline
\end{tabular}

Means followed by the same small letter in the row and capital letter in the column do not differ among themselves by the Tukey test at the level of $5 \%$ of significance. PS: pig slurry; DAS: days after seeding.

Concentrations of $\mathrm{K}$ were low in the soil, which could have been due to plant absorption. After the crops reached the maturation phase, soil $\mathrm{K}$ concentrations increased because this element was only found in a soluble mineral form in pig slurry, thus, increasing its absorption potential and resulting in its small residual effect, especially for grasses (Ceretta et al. 2003). Sodium $(\mathrm{Na})$ concentrations in the soil (Table 7) were lower than $\mathrm{Ca}$ concentrations (Table 6) due to leaching, which reduced the soluble salt accumulation in the soil. Despite the possible increase over the time with successive applications, $\mathrm{Na}$ indices in the soil were low and did not present any environmental concern (Cordeiro 2001). Contrary to acidic soils, in which the leaching mechanism promotes removal of basic cations from the soil, in other cases salty 
soils develop as a consequence of salt accumulation, especially $\mathrm{Na}$. This can be worsened by irrigation if the water used adds salt to the soil (Marschner 1995). In this context, it was observed that the sodium adsorption rate (SAR) values tended to increase as a function of pig slurry dose and time, but the values were extremely low, which did not lead to sodification problems (Table 7). Reduced Na concentration in the soil in the last sampling (200 DAS) was similar to the last but one sampling (95 DAS) (Table 7). This could have been due to the use of irrigation without pig slurry during the maturation phase. These observations indicated that humid climates would rarely accumulate $\mathrm{Na}$ because of the large amount of precipitation, which promoted leaching
(Rengasamy and Olsson 1993). However, this depends on how much of the element is applied, which is a function of wastewater quality and the volume applied, especially for repeated pig slurry applications over a long period.

Similar to SAR, soil exchangeable sodium percentage (ESP) also increased (Table 7) proportionally to pig slurry dose. However, all of the observed ESP values were below $15 \%$ considered to be an environmental indicator (Richards 1954). Comparing pig slurry composition (Table 1) with elements concentrations in the leachate (Tables 9 and 10), cation leaching was low. However, highest slurry levels resulted in higher concentrations of elements in the leachate.

Table 7 - Tukey test for the significant parameters of soil, in the interaction PS*DAS $\left(\mathrm{NO}_{3}, \mathrm{NH}_{4}, \mathrm{P}, \mathrm{K}, \mathrm{Ca}\right)$.

\begin{tabular}{|c|c|c|c|c|c|}
\hline \multirow[t]{3}{*}{ SW $\left(\mathrm{m}^{3} \mathrm{ha}^{-1}\right)$} & \multicolumn{5}{|c|}{ DAS } \\
\hline & $\mathbf{0}$ & 40 & 70 & 95 & 200 \\
\hline & \multicolumn{5}{|c|}{$\mathrm{NO}_{3}\left(\mathrm{mg} \mathrm{L}^{-1}\right)$} \\
\hline 0 & $41.86 \mathrm{bA}$ & $60.21 \mathrm{aA}$ & $66.40 \mathrm{aA}$ & $47.85 \mathrm{bB}$ & $43.53 \mathrm{bA}$ \\
\hline 112.5 & $38.00 \mathrm{bB}$ & $58.44 \mathrm{aA}$ & $58.08 \mathrm{aA}$ & 49.79abAB & 48.98abA \\
\hline 225 & $51.75 \mathrm{aAB}$ & $53.29 \mathrm{aA}$ & $57.67 \mathrm{aA}$ & $56.87 \mathrm{aAB}$ & $46.82 \mathrm{aA}$ \\
\hline 337.5 & $41.7 \mathrm{bA}$ & $58.62 \mathrm{abA}$ & $63.23 \mathrm{aA}$ & $60.41 \mathrm{aAB}$ & $51.85 \mathrm{bA}$ \\
\hline \multirow[t]{2}{*}{450} & $51.80 \mathrm{abAB}$ & $56.47 \mathrm{abA}$ & $55.36 \mathrm{abA}$ & $67.39 \mathrm{aA}$ & $46.89 \mathrm{bA}$ \\
\hline & \multicolumn{5}{|c|}{$\mathrm{NH}_{4}\left(\mathrm{mg} \mathrm{L}^{-1}\right)$} \\
\hline 0 & $4.21 \mathrm{aA}$ & $4.47 \mathrm{aA}$ & $4.23 \mathrm{aA}$ & $4.58 \mathrm{aA}$ & $4.37 \mathrm{aA}$ \\
\hline 112.5 & $3.96 \mathrm{bA}$ & 4.06abA & 4.10abcB & $4.63 \mathrm{aA}$ & $4.70 \mathrm{aA}$ \\
\hline 225 & $3.93 \mathrm{cA}$ & $4.37 \mathrm{abA}$ & $4.07 \mathrm{abA}$ & $4.62 \mathrm{aA}$ & $4.86 \mathrm{aA}$ \\
\hline 337.5 & $3.82 \mathrm{bA}$ & $4.16 \mathrm{abA}$ & $3.94 \mathrm{bA}$ & $4.68 \mathrm{aA}$ & $4.78 \mathrm{aA}$ \\
\hline \multirow[t]{2}{*}{450} & $4.03 \mathrm{bcA}$ & $4.07 \mathrm{bcA}$ & $3.74 \mathrm{cA}$ & 4.61abA & $4.86 \mathrm{aA}$ \\
\hline & \multicolumn{5}{|c|}{$\mathrm{P}\left(\mathrm{mg} \mathrm{L}^{-1}\right)$} \\
\hline 0 & $14.62 \mathrm{aAB}$ & $14.66 \mathrm{aA}$ & $14.79 \mathrm{aA}$ & $14.06 \mathrm{aC}$ & $14.26 \mathrm{aB}$ \\
\hline 112.5 & $13.40 \mathrm{bB}$ & $13.89 \mathrm{bA}$ & $13.93 \mathrm{bA}$ & $21.98 \mathrm{aB}$ & $14.38 \mathrm{bB}$ \\
\hline 225 & $16.85 \mathrm{bA}$ & $16.27 \mathrm{bA}$ & $17.03 \mathrm{bA}$ & $26.24 \mathrm{aAB}$ & $22.64 \mathrm{aA}$ \\
\hline 337.5 & $11.22 \mathrm{bB}$ & $13.99 \mathrm{bA}$ & $17.43 \mathrm{abA}$ & $24.63 \mathrm{aAB}$ & 17.05abAB \\
\hline \multirow[t]{2}{*}{450} & $13.57 \mathrm{bAB}$ & $15.83 \mathrm{bA}$ & $19.22 \mathrm{bA}$ & $29.70 \mathrm{aA}$ & $16.73 \mathrm{bAB}$ \\
\hline & \multicolumn{5}{|c|}{$\mathrm{K}\left(\mathrm{mg} \mathrm{L}^{-1}\right)$} \\
\hline 0 & $2.93 \mathrm{aA}$ & $3.85 \mathrm{aA}$ & $4.06 \mathrm{aA}$ & $3.81 \mathrm{aAB}$ & $3.38 \mathrm{aAB}$ \\
\hline 112.5 & $0.99 \mathrm{bB}$ & 1.39abB & $1.96 \mathrm{abB}$ & $2.39 \mathrm{aB}$ & $2.19 \mathrm{aB}$ \\
\hline 225 & $1.22 \mathrm{cB}$ & $2.33 \mathrm{bcB}$ & $2.27 \mathrm{abB}$ & $3.47 \mathrm{aB}$ & $2.42 \mathrm{abAB}$ \\
\hline 337.5 & $0.85 \mathrm{cB}$ & $1.76 \mathrm{bcB}$ & $2.09 \mathrm{bB}$ & $3.97 \mathrm{aAB}$ & $3.68 \mathrm{aA}$ \\
\hline \multirow[t]{2}{*}{450} & $0.74 \mathrm{cB}$ & $1.64 \mathrm{cB}$ & $3.08 \mathrm{aB}$ & $5.06 \mathrm{aA}$ & $3.54 \mathrm{abA}$ \\
\hline & \multicolumn{5}{|c|}{$\mathrm{Ca}\left(\mathrm{mmol}_{\mathrm{c}} \mathrm{dm}^{-3}\right)$} \\
\hline 0 & $49.16 \mathrm{aA}$ & $46.16 \mathrm{aA}$ & $33.00 \mathrm{aB}$ & $33.00 \mathrm{aB}$ & $38.00 \mathrm{aC}$ \\
\hline 112.5 & $52.83 \mathrm{aA}$ & $62.66 \mathrm{aA}$ & $61.16 \mathrm{aA}$ & $62.83 \mathrm{aA}$ & $60.16 \mathrm{aAB}$ \\
\hline 225 & $68.50 \mathrm{aA}$ & $63.00 \mathrm{aA}$ & $66.83 \mathrm{aA}$ & $49.16 \mathrm{aA}$ & $56.66 \mathrm{aBC}$ \\
\hline 337.5 & $51.33 \mathrm{aA}$ & $53.66 \mathrm{~A}$ & $58.83 \mathrm{aA}$ & $66.16 \mathrm{aA}$ & $71.00 \mathrm{aAB}$ \\
\hline 450 & $45.00 \mathrm{bA}$ & $57.66 \mathrm{bA}$ & $68.33 \mathrm{abA}$ & $94.66 \mathrm{aA}$ & $94.66 \mathrm{aA}$ \\
\hline
\end{tabular}

Means followed by the same small letter in the row and capital letter in the column do not differ among themselves by the Tukey test at the level of $5 \%$ of significance. PS: pig slurry; DAS: days after seeding; SAR: sodium adsorption ratio; ESP: exchangeable sodium percentage.

Table 9 showed that $\mathrm{K}$ levels tended to increase over time, even though the levels remained low. In the 60 DAS, K levels on soil were $1.02 \mathrm{meq}^{-1}$, $1.23 \mathrm{meq} \mathrm{L} \mathrm{L}^{-1}, 1.10 \mathrm{meq} \mathrm{L}^{-1}$ and $1.03 \mathrm{meq} \mathrm{L}^{-1}$ in doses of $112.5 \mathrm{~m}^{3} \mathrm{ha}^{-1}, 225 \mathrm{~m}^{3} \mathrm{ha}^{-1}, 337.5 \mathrm{~m}^{3} \mathrm{ha}^{-1}$ and $450 \mathrm{~m}^{3} \mathrm{ha}^{-1}$, respectively. These levels increased to $1.12 \mathrm{meq} \mathrm{L}^{-1}, 1.35 \mathrm{meq} \mathrm{L}^{-1}, 1.40 \mathrm{meq}$ $\mathrm{L}^{-1}$ and 1.17 meq $\mathrm{L}^{-1}$ in 150 DAS, respectively. 
These low levels of $\mathrm{K}$ in the leachate could be due to the low concentration in slurry (Table 1).

$\mathrm{Ca}$ and $\mathrm{Mg}$ concentrations shown in Table 9 indicated low mobility of these elements, which could be attributed to the high retention of cations in the soil, as well as interaction with anions not adsorbed by the soil lime and clay. Almost all of the added $\mathrm{Ca}$ and $\mathrm{Mg}$ moved toward the negative charges created by the increase in $\mathrm{pH}$, and only a small fraction of the $\mathrm{Ca}$ and $\mathrm{Mg}$ was part of the soil solution. Thus, $\mathrm{Ca}$ and $\mathrm{Mg}$ changes in the profile depended on the existence of anions in the soil solution, especially nitrates, chlorides and sulfates, which mainly resulted from the mineralization of $\mathrm{OM}$ and whose quantities might explain, at least in part, the different effects of lime on mobility in various soils (Pearson et al. 1962; Gonzalez-Erico et al. 1979).

Average Na levels in the leachate (Table 10) at 60 and 75 DAS (beginning of the period) differed from the Na level after 90 DAS. At 90 DAS, Na had higher concentrations, but the $\mathrm{Na}$ concentrations were still below that the Brazilian limit for underground water (CONAMA 2008). Therefore, SAR values (Table 8) from the leachate showed a medium restriction, but EC value showed low environmental restriction (Maas and Hoffman 1977; Cordeiro 2001).

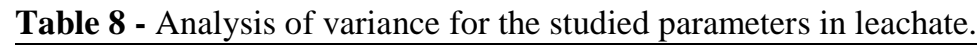

\begin{tabular}{|c|c|c|c|c|c|c|c|c|c|c|c|}
\hline \multirow{2}{*}{$\begin{array}{l}\text { Causes of } \\
\text { Variation }\end{array}$} & \multirow{2}{*}{ DF } & \multicolumn{10}{|c|}{$\mathbf{F}$} \\
\hline & & TKN & $\mathrm{NO}_{3}^{-}$ & $\mathbf{P}$ & $\mathbf{K}$ & $\mathbf{C a}$ & Mg & $\mathbf{N a}$ & pH & EC & SAR \\
\hline Block & 2 & $0.92^{\mathrm{ns}}$ & $3.97^{\mathrm{ns}}$ & $3.20^{\mathrm{ns}}$ & $1.28^{\mathrm{ns}}$ & $1.09^{\mathrm{ns}}$ & $0.78^{\text {ns }}$ & $4.08^{\mathrm{ns}}$ & $3.20^{\mathrm{ns}}$ & $3.29^{\mathrm{ns}}$ & $4.25^{\mathrm{ns}}$ \\
\hline PS & 3 & $1.99^{\mathrm{ns}}$ & $2.55^{\mathrm{ns}}$ & $0.84^{\mathrm{ns}}$ & $0.86^{\mathrm{ns}}$ & $7.86^{\mathrm{ns}}$ & $6.22^{\mathrm{ns}}$ & $0.746^{\mathrm{ns}}$ & $0.84^{\mathrm{ns}}$ & $8.06 *$ & $0.09^{\mathrm{ns}}$ \\
\hline Error I & 6 & & & & & & & & & & \\
\hline $\mathrm{CF}$ & 1 & $1.60^{\mathrm{ns}}$ & $0.10^{\mathrm{ns}}$ & $0.14^{\mathrm{ns}}$ & $0.02^{\mathrm{ns}}$ & $0.09^{\mathrm{ns}}$ & $0.10^{\mathrm{ns}}$ & $1.15^{\mathrm{ns}}$ & $0.14^{\mathrm{ns}}$ & $0.02^{\mathrm{ns}}$ & $0.207^{\mathrm{ns}}$ \\
\hline $\mathrm{PS} * \mathrm{CF}$ & 3 & $1.29^{\mathrm{ns}}$ & $0.48^{\mathrm{ns}}$ & $1.08^{\mathrm{ns}}$ & $0.08^{\mathrm{ns}}$ & $0.78^{\mathrm{ns}}$ & $0.13^{\mathrm{ns}}$ & $0.15^{\mathrm{ns}}$ & $1.08^{\mathrm{ns}}$ & $0.24^{\mathrm{ns}}$ & $0.23^{\mathrm{ns}}$ \\
\hline Error II & 8 & & & & 6.71 & & & & & & \\
\hline DAS & 6 & $13.84 *$ & $3.01 *$ & $8.06^{*}$ & $2.74 *$ & $8.89^{*}$ & $18.22 *$ & $12.57 *$ & $8.06^{*}$ & $4.41 *$ & $5.82 *$ \\
\hline PS*DAS & 18 & $1.08^{\mathrm{ns}}$ & $2.17 *$ & $1.27^{\mathrm{ns}}$ & $1.61 *$ & $0.98^{\mathrm{ns}}$ & $2.07^{\mathrm{ns}}$ & $1.05^{\mathrm{ns}}$ & $1.27^{\mathrm{ns}}$ & $1.34^{\mathrm{ns}}$ & $5.01 *$ \\
\hline $\mathrm{CF}^{*} \mathrm{DAS}$ & 6 & $0.35^{\mathrm{ns}}$ & $0.78^{\mathrm{ns}}$ & $1.74^{\mathrm{ns}}$ & $0.55^{\mathrm{ns}}$ & $1.38^{\mathrm{ns}}$ & $1.43^{\mathrm{ns}}$ & $0.78^{\mathrm{ns}}$ & $1.74^{\mathrm{ns}}$ & $3.28 *$ & $0.38^{\text {ns }}$ \\
\hline $\mathrm{PS} * \mathrm{CF} * \mathrm{DAS}$ & 18 & $0.81^{\mathrm{ns}}$ & $1.43^{\mathrm{ns}}$ & $1.11^{\mathrm{ns}}$ & $0.93^{\mathrm{ns}}$ & $1.09^{\mathrm{ns}}$ & $3.09^{\mathrm{ns}}$ & $0.48^{\mathrm{ns}}$ & $1.11^{\mathrm{ns}}$ & $1.60^{\mathrm{ns}}$ & $1.27^{\mathrm{ns}}$ \\
\hline Block*DAS & 84 & $0.82^{\mathrm{ns}}$ & $0.44^{\mathrm{ns}}$ & $3.65 *$ & & $2.01 *$ & $2.45^{*}$ & $2.56^{*}$ & $3.65 *$ & $0.75^{\mathrm{ns}}$ & $1.52^{\mathrm{ns}}$ \\
\hline Error III & 12 & & & & & & & & & & \\
\hline Total & 167 & & & & & & & & & & \\
\hline CV I (\%) & & 32.21 & 37.04 & 16.18 & 41.12 & 20.73 & 28.08 & 59.78 & 16.18 & 66.92 & 28.71 \\
\hline CV II (\%) & & 34.26 & 51.69 & 15.02 & 53.04 & 44.50 & 27.25 & 63.56 & 15.02 & 66.53 & 4.38 \\
\hline CV III (\%) & & 29.20 & 18.22 & 4.99 & 19.26 & 2.01 & 11.85 & 37.39 & 4.99 & 31.09 & 11.89 \\
\hline
\end{tabular}

DF: Degrees of freedom; CF: chemical fertilization; PS: pig slurry; DAS: days after seeding; CV: coefficient of variation; TKN: total Kjeldahl nitrogen; EC: electrical conductivity; SAR: sodium adsorption ratio; ESP: exchangeable sodium percentage.

Table 9 - Tukey test for the parameters of leachate, concerning the significant interaction PS*DAS (NO $, \mathrm{K}, \mathrm{SAR})$.

\begin{tabular}{|c|c|c|c|c|c|c|c|}
\hline \multirow{2}{*}{$\begin{array}{l}\text { Pig slurry } \\
\left(\mathbf{m}^{3} \mathbf{h a}^{-1}\right)\end{array}$} & \multicolumn{7}{|c|}{ DAS } \\
\hline & 60 & 75 & 90 & 105 & 120 & 135 & 150 \\
\hline \multicolumn{8}{|c|}{$\mathrm{NO}_{3}\left(\mathrm{mg} \mathrm{L}^{-1}\right)$} \\
\hline 112.5 & $0.00 \mathrm{aB}$ & $0.16 \mathrm{aB}$ & $0.16 \mathrm{aB}$ & $0.16 \mathrm{aB}$ & $0.16 \mathrm{aB}$ & $0.16 \mathrm{aB}$ & $0.16 \mathrm{aB}$ \\
\hline 225 & $0.33 \mathrm{bAB}$ & $0.33 \mathrm{bAB}$ & $0.50 \mathrm{aAB}$ & $0.33 \mathrm{bB}$ & $0.33 \mathrm{bB}$ & $0.33 \mathrm{bB}$ & $0.33 \mathrm{bB}$ \\
\hline 337.5 & $0.66 \mathrm{aA}$ & $0.66 \mathrm{aAB}$ & $0.50 \mathrm{bAB}$ & $0.63 \mathrm{aAB}$ & $0.66 \mathrm{aAB}$ & $0.66 \mathrm{aAB}$ & $0.66 \mathrm{aB}$ \\
\hline 450 & $0.66 \mathrm{bA}$ & $0.83 \mathrm{abA}$ & $0.83 \mathrm{abA}$ & $1.00 \mathrm{aA}$ & $1.16 \mathrm{aA}$ & $1.50 \mathrm{aA}$ & $1.16 \mathrm{aA}$ \\
\hline \multicolumn{8}{|c|}{$\mathrm{K}\left(\mathrm{meq} \mathrm{L} \mathrm{L}^{-1}\right)$} \\
\hline 112.5 & $1.02 \mathrm{cA}$ & $1.12 \mathrm{bcA}$ & $1.25 \mathrm{abA}$ & $1.52 \mathrm{abA}$ & $1.33 \mathrm{abA}$ & $1.58 \mathrm{aB}$ & $1.12 \mathrm{bcA}$ \\
\hline 225 & $1.23 \mathrm{bA}$ & $1.36 \mathrm{abA}$ & $1.31 \mathrm{abA}$ & $1.29 \mathrm{bA}$ & $1.34 \mathrm{abA}$ & $1.76 \mathrm{aA}$ & $1.35 \mathrm{abA}$ \\
\hline 337.5 & $1.10 \mathrm{bA}$ & $1.25 \mathrm{abA}$ & $1.40 \mathrm{abA}$ & $1.46 \mathrm{abA}$ & $1.55 \mathrm{aA}$ & $1.27 \mathrm{abB}$ & $1.40 \mathrm{abA}$ \\
\hline 450 & $1.03 \mathrm{cA}$ & $1.13 \mathrm{abA}$ & $1.32 \mathrm{abcA}$ & $1.60 \mathrm{aA}$ & $1.49 \mathrm{abA}$ & $1.50 \mathrm{abA}$ & $1.17 \mathrm{abcA}$ \\
\hline \multicolumn{8}{|c|}{ SAR $\left(\right.$ meq L $\left.^{-1}\right)$} \\
\hline 112.5 & $13.16 \mathrm{bB}$ & $14.66 \mathrm{aA}$ & $15.83 \mathrm{aA}$ & $15.83 \mathrm{aB}$ & $15.83 \mathrm{aB}$ & $13.83 \mathrm{abC}$ & $13.33 \mathrm{bB}$ \\
\hline 225 & $14.50 \mathrm{~A}$ & $14.50 \mathrm{~A}$ & $14.83 \mathrm{~A}$ & $15.83 \mathrm{~B}$ & $16.00 \mathrm{~B}$ & $16.83 \mathrm{BC}$ & $18.16 \mathrm{AB}$ \\
\hline 337.5 & $11.67 \mathrm{bB}$ & $11.00 \mathrm{Bb}$ & 16.00Aab & 16.33abB & 16.66abB & $17.33 \mathrm{aAB}$ & $19.33 \mathrm{aAB}$ \\
\hline 450 & $13.00 \mathrm{bcB}$ & $14.00 \mathrm{cA}$ & $15.83 \mathrm{abA}$ & $19.00 \mathrm{abA}$ & 19.50abA & $23.83 \mathrm{aA}$ & $23.50 \mathrm{aA}$ \\
\hline
\end{tabular}

Means followed by the same capital letter in the row and small letter in the column do not differ among themselves by Tukey test at the level of $5 \%$ significance. PS: pig slurry; DAS: days after seeding; SAR: sodium adsorption ratio. 
Table 10 - Test of means comparison for significant parameters of leachate among the levels of DAS (P, TKN, EC, $\mathrm{pH}, \mathrm{Ca}, \mathrm{Mg}, \mathrm{Na}$ ) and in $\mathrm{CF}^{*} \mathrm{DAS}(\mathrm{EC})$ interaction.

\begin{tabular}{cccccccc}
\hline & \multicolumn{7}{c}{ DAS } \\
\cline { 2 - 8 } Parameters & $\mathbf{6 0}$ & $\mathbf{7 5}$ & $\mathbf{9 0}$ & $\mathbf{1 0 5}$ & $\mathbf{1 2 0}$ & $\mathbf{1 3 5}$ & $\mathbf{1 5 0}$ \\
\hline $\mathrm{P}\left(\mathrm{mg} \mathrm{L}^{-1}\right)$ & $0.0024 \mathrm{c}$ & $0.00058 \mathrm{~d}$ & $0.0023 \mathrm{c}$ & $0.00078 \mathrm{~d}$ & $0.0332 \mathrm{~b}$ & $0.0535 \mathrm{a}$ & $0.0445 \mathrm{ab}$ \\
$\mathrm{TKN}\left(\mathrm{mg} \mathrm{L}^{-1}\right)$ & $0.00 \mathrm{c}$ & $0.00 \mathrm{c}$ & $0.416 \mathrm{a}$ & $0.416 \mathrm{a}$ & $0.416 \mathrm{a}$ & $0.416 \mathrm{a}$ & $0.25 \mathrm{~b}$ \\
$\mathrm{EC}\left(\mathrm{mg} \mathrm{L}^{-1}\right)$ & $73.54 \mathrm{~b}$ & $75.33 \mathrm{~b}$ & $97.70 \mathrm{ab}$ & $85.08 \mathrm{ab}$ & $78.37 \mathrm{~b}$ & $102.83 \mathrm{a}$ & $98.75 \mathrm{ab}$ \\
$\mathrm{pH}\left(\mathrm{mg} \mathrm{L}^{-1}\right)$ & $6.87 \mathrm{ab}$ & $6.70 \mathrm{bc}$ & $6.87 \mathrm{ab}$ & $6.50 \mathrm{c}$ & $7.04 \mathrm{ab}$ & $7.08 \mathrm{a}$ & $6.87 \mathrm{ab}$ \\
$\mathrm{Ca}\left(\mathrm{mg} \mathrm{L}^{-1}\right)$ & $0.79 \mathrm{c}$ & $1.29 \mathrm{bc}$ & $1.91 \mathrm{ab}$ & $2.41 \mathrm{a}$ & $2.45 \mathrm{a}$ & $2.54 \mathrm{a}$ & $2.41 \mathrm{a}$ \\
$\mathrm{Mg}\left(\mathrm{mg} \mathrm{L}^{-1}\right)$ & $0.58 \mathrm{~b}$ & $0.75 \mathrm{~b}$ & $1.37 \mathrm{ab}$ & $0.916 \mathrm{ab}$ & $1.54 \mathrm{ab}$ & $1.66 \mathrm{a}$ & $1.20 \mathrm{ab}$ \\
$\mathrm{Na}\left(\mathrm{mg} \mathrm{L}^{-1}\right)$ & $15.50 \mathrm{~b}$ & $18.58 \mathrm{~b}$ & $29.33 \mathrm{a}$ & $30.958 \mathrm{a}$ & $33.45 \mathrm{a}$ & $32.45 \mathrm{a}$ & $33.75 \mathrm{a}$ \\
\hline \multicolumn{7}{c}{$\mathrm{DAS}$} \\
\cline { 2 - 8 } $\mathrm{CF}$ & 60 & 75 & 90 & 105 & 120 & 135 \\
\hline $50 \%$ & $75.50 \mathrm{aA}$ & $78.00 \mathrm{aA}$ & $96.00 \mathrm{aA}$ & $80.42 \mathrm{aA}$ & $75.50 \mathrm{aA}$ & $92.66 \mathrm{aA}$ & $90.16 \mathrm{aA}$ \\
$75 \%$ & $56.58 \mathrm{cB}$ & $72.66 \mathrm{bcA}$ & $99.42 \mathrm{abA}$ & $89.75 \mathrm{abcA}$ & $81.25 \mathrm{abcA}$ & $113.00 \mathrm{aA}$ & $107.33 \mathrm{aA}$ \\
\hline
\end{tabular}

Means followed by the same small letter in the row and capital letter in the column do not differ among themselves by Tukey test at the level of 5\% significance. DAS: days after seeding; TKN: total Kjeldahl nitrogen; CF: chemical fertilizer; EC: electric conductivity.

\section{Heavy Metals}

Zinc $(\mathrm{Zn})$ and copper $(\mathrm{Cu})$ are added to pig feed and are present in pig slurry, thus making an analysis of their environmental contamination valid. Table 7 shows that $\mathrm{Zn}$ levels in the soil were higher for the slurry doses of 337.5 and $450 \mathrm{~m}^{3} \mathrm{ha}^{-1}$ compared to the other doses.

In addition, $\mathrm{Cu}$ tended to be higher in soil at the applied doses compared to the control treatment at 0 DAS (Table 7). Both metals, however, did not accumulate over the experimental period (DAS). These metals might have been absorbed by the crop at the beginning of the growth cycle (Lopes 1995; Matias 2006) as well as adsorbed to the soil surface.

\section{Organic Material and pH}

Application of pig slurry significantly raised these levels to an OM content of $21.90 \mathrm{~g} \mathrm{dm}^{-3}$ and a $\mathrm{pH}$ of 6.30. Before the planting, the soil had an average OM content of $14.00 \mathrm{~g} \mathrm{dm}^{-3}$ and a $\mathrm{pH}$ of 5.47 (Table 2). Soil moved from "low" to "medium/high" for OM (Tomé Jr 1997) and from moderate acidity to near the neutrality desired for the plant growth (Lopes 1995). This $\mathrm{OM}$ and $\mathrm{pH}$ increase, which was probably a direct consequence of the biological organic demand (BOD) of the pig slurry and might have contributed to $\mathrm{Zn}$ and $\mathrm{Cu}$ fixation in the soil (Matos et al. 1997). This increase in OM needs to be further monitored in order to evaluate the real effect of the pig slurry application on this soil quality parameter.

\section{Agronomic parameters}

The analysis of variance for the agronomic parameters of corn crop revealed no significant effect on corn production for the following factors: pig slurry, chemical fertilization or the interaction between pig slurry and chemical fertilization ( $p$ values of $0.327,1.41$ and 0.41 , respectively). However, crop production was only measured at the end of the crop cycle. Therefore, time factor (DAS) was not included. The $p$-values were also not significant for plant height, except for the pig slurry and chemical fertilization factors ( 0.03 and 0.046 , respectively).

On average, the corn production was $1.16,0.880$, 1.30, 1.44 and $1.49 \mathrm{t} \mathrm{ha}^{-1}$ with $50 \%$ chemical fertilizer and 1.53, 0.960, 1.37, 1.48 and $1.80 \mathrm{t} \mathrm{ha}^{-1}$ with $75 \%$ chemical fertilizer for $0,112.5,225$, 337.5 and $450 \mathrm{~m}^{3} \mathrm{ha}^{-1}$ of pig slurry, respectively. The production increased $23 \%$ for the treatments receiving the highest level of pig slurry and largest dose of chemical fertilizer (PS*CF) compared to the control, which corroborated the results of Chateaubriand (1988) and Freitas et al. (2004). However, the production obtained didn't reach the regular corn production in this period in Brazil (from 3 to $4 \mathrm{t} \mathrm{ha}^{-1}$ ), probably due to the fact that the chemical fertilizer was applied just in the seeding.

The plants receiving $225,337.5$ and $450 \mathrm{~m}^{3} \mathrm{ha}^{-1}$ of pig slurry had equal shoot lengths $(93.66,93.30$ and $100.96 \mathrm{~cm}$, respectively) at a $5 \%$ significance level, and these plants had shoot lengths longer than those of plants receiving $112.5 \mathrm{~m}^{3} \mathrm{ha}^{-1} \mathrm{pig}$ slurry and the control treatment (average lengths 
of 85.09 and $83.26 \mathrm{~cm}$, respectively). Longer shoot lengths after pig slurry application were also observed by Freitas et al. (2004), Baumgartner et al. (2007) and Cruz et al. (2008), who studied corn, lettuce and passion fruit, respectively.

The primary factor for these proportional relations could be the relationship between the vegetative growth of corn and the amount of $\mathrm{N}$ applied (Barcellos 1992). Moreover, pig slurry provided several small amounts of different nutrients to the crop, which were not supplied by the mineral fertilization.

\section{CONCLUSION}

Considering that this was the first year in the experimental agricultural area and that pig slurry was applied together with the chemical fertilizer, it could be conclude that nitrate concentrations in the leachate increased as the amount of applied pig slurry increased, but these concentrations did not exceed the levels established by the law. Probably the continuous use of wastewater might cause environmental problems in the soil or in underground water due to its accumulation.

From a production point of view, more studies need to be done to determine the optimal use of pig slurry or/and chemical fertilizer in corn cultivation. From a sustainability viewpoint, the results indicated that pig slurry could be disposed of on soil and water systems used for corn cultivation. However, medium- and long-term studies need to be performed to determine the specific needs for each region.

\section{ACKNOWLEDGMENTS}

The authors gratefully acknowledge the financial support of $\mathrm{CNPq}$ (Conselho Nacional de Desenvolvimento Científico), CAPES (Coordenação de Aperfeiçoamento de Pessoal de Nível Superior), UNIOESTE (Western Paraná State University) and PGEAGRI (Post-graduation of Agricultural Engineering).

\section{REFERENCES}

Aboukhaled A, Alfaro JF, Smith M. Los lisímetros (Estudos FAO, irrigação e drenagem, 39). Roma: FAO; 1986.
Alfaia SS. Caracterização e distribuição das formas do nitrogênio orgânico em três solos da Amazônia Central. Acta Amaz. 2006; 36 (2): 135-140.

Anami MH, Sampaio SC, Suszek M, Damasceno S, Queiroz MMF. Deslocamento miscível de nitrato e fosfato proveniente de água residuária da suinocultura em colunas de solo. Rev Bras Eng Agríc Amb 2008; 12 (1): 75-80.

Anami MH, Sampaio SC, Suszek M, Frigo EP. Lixiviação de nitrato e fosfato proveniente de água residuária da suinocultura tratada em sistema de lagoas. Irriga. 2007; 12 (2): 192-201.

APHA, AWWA, WPCF. Standard methods for the examination of water and wastewater. 20th ed. Washington: American Public Health Association; 1998.

Barcellos LAR. Avaliação do potencial fertilizante do esterco líquido de bovinos [MS thesis]. Santa Maria, Brazil: Universidade Federal de Santa Maria, Departamento de Engenharia Agrícola; 1992.

Barros FM, Martinez MA, Neves JCL, Matos AT, Silva DD. Características químicas do solo influenciadas pela adição de água residuária da suinocultura. Rev Bras Eng Agríc Amb. 2005; 9: 47-51.

Basso CJ, Ceretta CA, Durigon R, Poletto N, Girotto E. Dejeto líquido de suínos II - perdas de nitrogênio e fósforo por percolação no solo sob plantio direto. Rev Ciênc Rural. 2005; 35 (6): 1305-1312.

Baumgarnter D, Sampaio SC, Silva TR, Vilas Boas MA. Reúso de águas residuárias da piscicultura e da suinocultura na irrigação da cultura da alface. Rev Eng Agríc. 2007; 27 (1): 152-163.

Berenguer P, Cela S, Santiveri F, Boixadera J, Lloveras J. Copper and Zinc soil accumulation and plant concentration in irrigated maize fertilized with liquid swine manure. Agron J. 2008; 100 (4): 1056-1061.

Berwanger AL, Ceretta CA, Santos DR dos. Alterações do teor de fósforo no solo com aplicações de dejetos líquidos de suínos. Rev Bras Ciênc Solo. 2008; 32 (6): 2525-2532.

Brito FL, Rolim MM, Silva JAA da, Pedrosa EMR. Qualidade do percolado de solos que receberam vinhaça em diferentes doses e tempo de incubação. Rev Bras Eng Agríc Amb. 2007; 11 (7): 318-323.

Caovilla FA, Sampaio SC, Pereira JO, Vilas Boas MA, Gomes BME, Figueiredo AC. Lixiviação de nutrientes provenientes de águas residuárias em colunas de solo cultivados com soja. Rev Bras Eng Agríc Ambiental. 2005; 9: 283-287.

Ceretta CA, Basso CJ, Pavinato PS, Trentin EE, Girotto E. Produtividade de grãos de milho, produção de matéria seca e acúmulo de nitrogênio, fósforo e potássio na rotação aveia preta/milho/nabo forrageiro com aplicação de dejeto líquido de suínos. Ciênc Rural. 2005; 35 (6): 1287-1295.

Ceretta CA, Durigon R, Basso CJ, Barcellos LAR, Vieira FCB. Características químicas de solo sob 
aplicação de esterco líquido de suínos em pastagem natural. Pesqui Agropecu Bras. 2003; 38: 729-735.

Chateaubriand AD. Efeito de dejetos de suínos, aplicados em irrigação por sulco, na cultura do milho (Zea mays L) [MS Thesis]. Viçosa, Brazil: Universidade Federal de Viçosa, Engenharia Agrícola; 1988.

Brasil. Conselho Nacional do Meio Ambiente. Resolução $\mathrm{n}^{0}$ 396, de 3 de abril de 2008. Diário Oficial da União, Brasília, DF, 7 abr. 2008. Disponível em: http://www.mma.gov.br/port/conama /legiabre.cfm?codlegi=562. Acesso em: 2 fev. 2013.

Cruz MCM, Ramos JD, Oliveira DL, Marques VB, Hafle OM. Utilização de água residuária de suinocultura na produção de mudas de maracujazeiroazedo cv redondo amarelo. Rev Brasil Frut. 2008; 30 (4): 1107-1112.

Cordeiro GG. Qualidade da água para fins de irrigação (conceitos básicos e práticos) (Documentos, 167). Petrolina: Embrapa Semi-árido; 2001.

Dal Bosco TC, Iost C, Silva LN, Camellosi CF, Ebert DC, Schreiner JS, et al. Utilização de água residuária de suinocultura em propriedade agrícola - estudo de caso. Irriga. 2008b; 13 (1): 139-144.

Dal Bosco TC, Sampaio SC, Opazo MAU, Gomes SD, Nóbrega LHP. Aplicação de água residuária de suinocultura em solo cultivado com soja: cobre e zinco no material escoado e no solo. Rev Eng Agríc 2008a; 28 (4): 699-709.

Doblinski AF, Sampaio SC, Silva VR, Nóbrega LHPN, Gomes SD, Dal Bosco TC. Nonpoint source pollution by swine farming wastewater in bean crop. Rev Bras Eng Agríc Amb. 2010; 14 (1): 87-93.

Eghball B, Power JF, Gilley JE, Doran JW. Nutrient, carbon, and mass loss during composting of beef cattle feedlot manure. J Environ Qual. 1997; 26 (1): 189-193.

Embrapa. Empresa Brasileira de Pesquisa Agropecuária. Centro Nacional de Pesquisa de Solos. Sistema brasileiro de classificação de solos. Brasília: Embrapa; 1999.

Fancelli AL, Dourado Neto D. Produção de milho. Guaíba: Agropecuária; 2000.

Freitas WS, Oliveira RA, Pinto FA, Cecon PR, Galvão JCC. Efeito da aplicação de águas residuárias de suinocultura sobre a produção do milho para silagem. Rev Bras Eng Agríc Ambiental. 2004; 8 (1): 120-125.

Frigo EP, Sampaio SC, Freitas PSL, Queiroz MMF, Nóbrega LHP, Mallmann LS. Desempenho do sistema de gotejamento e de filtros utilizando água residuária da suinocultura. Irriga. 2006; 11 (3): 305318.

Gianello C, Bissani CA, Tedesco MJ. Princípios de fertilidade do solo. Porto Alegre: UFRGS, Departamento de Solos; 1995.
Gomes ERS, Sampaio SC, Corrêa MM, Vilas Boas MA, Alves LFA, Alves Sobrinho T. Movimento de nitrato proveniente de água residuária em colunas de solo. Rev Eng Agríc. 2004; 24 (3): 557-568.

Gomes FP. Curso de estatística experimental. 12th. ed. Piracicaba: Nobel; 1987.

Gonzalez-Erico E, Kamprath EJ, Naderman GC, Soares WV. Effect of depth of lime incorporation on growth of corn on an Oxisol of Central Brazil. Soil Sci Soc Am J. 1979; 43 (6): 1155-1158.

Halliwell DJ, Barlow KM, Nasch DM. A review of the effects of wastewater sodium on soil physical properties and their implications for irrigation systems. Aust J Soil Res. 2001; 39 (6): 1259-1267.

Hountin JA, Karam A, Couillard D, Cescas MP. Use of a fractionation procedure to assess the potential for $\mathrm{P}$ movement in a soil profile after 14 years of liquid pig manure fertilization. Agric Ecosyst Environ. 2000; 78: 77-84.

Longo AJ, Sampaio SC, Suszek M. Equação de chuvas intensas e precipitação provável para o município de Cascavel PR. Varia Sci. 2006; 6 (11): 119-127.

Lopes AS. Manual internacional de fertilidade do solo. Piracicaba: Potafos; 1995.

Maas EV, Hoffman GH. Crop salt tolerance: current assessment. J Irrig Drain Div-ASCE. 1977; 103 (2): 115-134.

Marschner H. Mineral nutrition of higher plants. Berlin: Academic Press; 1995.

Matias JL. Metais pesados em solos sob aplicação de dejetos líquidos de suínos em duas microbacias hidrográficas de Santa Catarina [PhD thesis]. Santa Maria, Brazil: Universidade Federal de Santa Maria, Departamento de Ciência do Solo; 2006.

Matos AT, Sediyama MAN, Freitas SP. Características químicas e microbiológicas do solo, influenciadas pela aplicação de dejeto liquido de suínos. Rev Ceres. 1997; 44 (254): 399-410.

Melo RF, Ferreira PA, Matos AT, Ruiz HA, Oliveira LB. Deslocamento de cátions básicos provenientes a agua residuária de mandioca em colunas de solo. Rev Bras Eng Agríc Amb. 2006; 10 (2): 456-465.

Oliveira E, Parizotto MLV. Características e uso fertilizante do esterco de suíno (Circular 83). Londrina: IAPAR; 1994.

Oliveira RA, Campelo PG, Matos AT, Martinez MA, Cecon PR. Influência da aplicação de águas residuárias de suinocultura na capacidade de infiltração de um solo Podzólico Vermelho-Amarelo. Rev Bras Eng Agríc Amb. 2000; 4 (2): 263-267.

Payet N, Findeling A, Chopart J, Feder F, Nicolini E, Macary HS, et al. Modelling the fate of nitrogen following pig slurry application on a tropical cropped acid soil on the island of Réunion (France). Agric Ecosyst Environ. 2009; 134 (3): 218-233. 
Pearson RW, Abruna F, Vice-Chandler J. Effect of lime and nitrogen application on downward movements of calcium and magnesium in two humid tropical soils of Puerto Rico. Soil Sci. 1962; 93 (1): 77-82.

Pelissari R, Sampaio SC, Gomes SD, Crepalli MS. Lodo têxtil e água residuária da suinocultura na produção de mudas de eucalyptus grandis (W, Hill ex Maiden). Eng Agríc. 2009; 29 (2): 288-300.

Raij BV, Andrade JC, Cantarella H, Quaggio JA. Análise química para avaliação da fertilidade de solos tropicais. Campinas: Instituto Agronômico; 2001.

Rengasamy P, Olsson KA. Irrigation and sodicity. Aust J Soil Res. 1993; 31 (6): 821-837.

Richards LA. Diagnosis and improvement of saline and alkali soils (Agriculture handbook, 60). Washington: United States Salinity Laboratory Staff: 1954.

Rotz CA. Management to reduce nitrogen losses in animal production. J Anim Sci. 2011; 82: E119- E 137.

Sampaio SC, Silvestro MG, Frigo EP, Borges CM. Relação entre série de sólidos e condutividade elétrica em diferentes águas residuárias. Irriga. 2007; 12(4): 557-562.
Singh P, Kanwar RS. Simulating $\mathrm{NO}_{3}-\mathrm{N}$ transport to subsurface drain flows as affected by tillage under continuos corn using modified RZWQM. T Asae. 1995; 38 (2): 499-506.

Stefanutti R, Malavolta E, Muraoka T. Recuperação do fósforo residual do solo, derivado de um termofosfato magnesiano com diferentes granulometrias e do superfosfato simples granulado. Sci Agríc. 1995; 52(2): 233-238.

Suszek M, Sampaio SC, Santos RF, Nunes OLGS, Damasceno S, Mallmann LS. Uso de água residuária da suinocultura na bioestabilização de resíduos verdes urbanos. Rev Bras Eng Agríc Amb. 2005; 9(4): 176180.

Tedesco MJ, Gianello C, Bissani CA, Bohnen H, Volk Weiss SJ. Análise de solo, plantas e outros materiais. Porto Alegre: UFRGS, Departamento de Solos; 1995.

Tomé Jr JB. Manual para interpretação de análises de solo. Guaíba: Agropecuária; 1997.

Zaimes GN, Schultz RC. Phosphorus in Agricultural Watersheds: a literature review. Ames: Department of Forestry; 2002. 